\title{
Albańska lekcja transformacji ekonomicznej Społeczno-ekonomiczne tło i konsekwencje „rewolucji piramidowej” 1997 r.
}

Wydarzenia, rozgrywające się wiosną 1997 r., zdają się stanowić we współczesnej historii Albanii kluczową cezurę, jako data graniczna całego procesu albańskiej transformacji, uwzględniając jego społeczne i ekonomiczne aspekty. Choć pozornie mechanizm wydarzeń, określanych mianem „rewolucji piramidowej”, odbiega od przemian dokonujących się w postkomunistycznych państwach bałkańskich, stanowi on przykład erupcji postaw anty-transformacyjnych, charakterystycznych dla ostatniej dekady XX stulecia. Pierwsze od XIX $w$. ludowe powstanie zbrojne na Batkanach, by przytoczyć określenie Bernda Jürgena Fischera ${ }^{1}$, skłaniało badaczy do przekonania o szczególnym i wyjątkowym „przypadku albańskim”, ale także kazało poszukiwać genezy katastrofy struktur państwowych nie tylko w sferze polityki i gospodarki, lecz również w osobliwej, może nawet wykraczajacej poza normy europejskie, mentalności Albańczyków.

W okresie rządów prezydenta Salego Berishy i stanowiacej jego zaplecze polityczne Demokratycznej Partii Albanii (Partia Demokratike e Shqipërisë, PDSh) państwo albańskie

${ }^{1}$ B.J. Fisher, Albania po 1989 roku: dziedzictwo Hodzy, [w:] Polityka Europy Środkowej i Potudniowo-Wschodniej po 1989 roku, pod red. S.P. Ramet, przeł. M. Gałaska [et al.], Warszawa 2012, s. 466. 
uchodziło za przykład skutecznie i konsekwentnie realizowanego procesu przywracania mechanizmów gospodarki rynkowej i demokracji parlamentarnej². Gdyby porównać stan bezpieczeństwa wewnętrznego, a także aktywność międzynarodowa Albanii na przestrzeni czterech pierwszych lat rzadów demokratów (1992-1996), można było odnieść wrażenie, że całkowicie zmieniło się oblicze państwa, a polityczny chaos i masowe ucieczki Albańczyków z kraju należą do bezpowrotnie minionej przeszłości. W obliczu trwającego konfliktu w Jugosławii, spokojna i stabilna Albania pod rządami Berishy zyskiwała na znaczeniu jako potencjalna baza wojskowa dla działań amerykańskich na Bałkanach, a zarazem cieszyła się poparciem Waszyngtonu i państw Europy Zachodniej ${ }^{3}$.

Niewielka znajomość realiów albańskich i przeszłości tego kraju wśród europejskich i amerykańskich polityków nie pozwalała na uświadomienie sobie prostego mechanizmu tworzenia „nowej” albańskiej klasy politycznej. Wobec braku jakiejkolwiek opozycji politycznej przed 1990 r., czy nawet środowisk, które można by nazwać opozycyjnymi, antykomunistami i demokratami stawali się zazwyczaj byli komuniści, wywodzący się z podrzędnych struktur aparatu Albańskiej Partii Pracy. Do nowej rzeczywistości wnosili oni aport w postaci absolutnej lojalności wobec kierownictwa partii

${ }^{2}$ Do 1996 r. Albania zajmowała czołowe miejsca w rankingu tempa wdrażania reform ekonomicznych przez państwa Europy Środkowej i Południowej, opracowanym przez ekspertów Międzynarodowego Funduszu Walutowego. Mimo wysokich wskaźników rozwoju gospodarczego Albanii, do $1996 \mathrm{r}$. nie udało się osiagnąć poziomu produkcji przemysłowej z końca lat 80. XX w., B. Vankovska, H. Viberg, Between Past and Future. Civil-Military Relations in the Post-Communist Balkans, London-New York 2003, s. 67; R. Morocco della Rocca, Shqiperia, rrenjet e nje krize, Tirana 2000, s. 66.

${ }^{3}$ A. Dybowska, Geneza i międzynarodowe implikacje konfliktu wewnatrzbatkańskiego z 1997 roku, [w:] Batkany. Etnokulturowe podtoże konfliktów, red. nauk. W. Konarski, A. Koseski, Pułtusk 2006, s. 123. 
rządzącej i umiejętności neutralizacji jej potencjalnych i urojonych wrogów. W epoce transformacji swoją misję, traktowaną z rewolucyjną bezwzględnościa, określali jako konieczność obrony Albanii przed powrotem komunizmu.

Podobnie jak w czasach króla Zoga I (1928-1939), czy w czasie dyktatury komunistycznej Envera Hoxhy, nie było miejsca dla alternatywnych sił politycznych, nie uformował się także zwyczaj pokojowego przekazywania władzy. Powstanie systemu politycznego, zdominowanego przez dwie partie - „postkomunistyczną” i „antykomunistyczną” - nie wynikało z istotnych różnic programowych, ale z rywalizacji dwóch środowisk, wywodzących się z byłej partii komunistycznej. Szukając dla siebie miejsca na scenie politycznej, główna siła opozycyjna - Socjalistyczna Partia Albanii (Partia Socialiste e Shqipërisë, PSSh) - określała się jako nowoczesna siła polityczna, która nie unika współpracy z Zachodem, ale ze względów społecznych dostrzega konieczność wyhamowania „terapii szokowej” i zwiększenia środków przeznaczonych na złagodzenie skutków transformacji ${ }^{4}$ Różnic między dwoma głównymi partiami należałoby się dopatrywać raczej w sporach personalnych i umiejętności podjęcia dialogu z idealizowanym Zachodem niż w sferze poglądów czy wartości. Dla większości społeczeństwa albańskiego pojęcie demokracji pozostawało abstrakcja, naznaczona przez okres dyktatury komunistycznej, a tworzenie państwa demokratycznego utrudniał brak jakichkolwiek instytucji demokratycznych czy nawet ich zalążków. Ograniczenie swobody wypowiedzi w albańskich mediach, typowe dla skłaniającego się ku metodom autorytarnym kierownictwa PDSh, nie pozwalało w pełni zweryfikować autentyczności obrazu Albanii, uciekającej

${ }^{4}$ A. Krasniqi, Partitë politike ne Shqipëri (1920-2006), Tirana 2006, s. $363-369$. 
od ponurego dziedzictwa czterdziestoletnich rządów Hoxhy i uczącego się mechanizmów demokracji.

Publicysta i analityk - Fatos Lubonja, szukając genezy wydarzeń 1997 r., zwracał uwagę na postępujacy proces alienacji nowej ekipy rządzącej, która - obejmując władzę w 1992 r. - była tak biedna, jak całe społeczeństwo, ale jej chciwość i wcześniejsze doświadczenia polityczne skłaniały do łączenia tendencji autorytarnych z przemożnym pragnieniem wydobycia się z egalitarnej nędzy minionej epoki ${ }^{5}$. Słowa Lubonji doskonale wpisują się w retorykę Petera Sloterdijka, który przejście od gospodarki nakazowej do gospodarki własnościowej określa jako zmianę systemu opartego o gniew i dumę na system oparty na pożądliwości ${ }^{6}$. Dla społeczeństwa kształtowanego przez kilka pokoleń w duchu komunistycznego egalitaryzmu ostentacyjne bogactwo rządzących stanowiło doświadczenie niezwykle frustrujące i budujace przepaść niezrozumienia między rządzacymi i rządzonymi.

W strategii monopolizacji władzy przez Demokratyczna Partię Albanii kluczowe znaczenie miało referendum konstytucyjne 1994 r., które przyniosło sromotną klęskę rządzącej partii. Projekt nowej konstytucji, wsparty autorytetem urzędującego prezydenta, został odrzucony nie tyle z powodu pojedynczych zapisów dotyczących polityki społecznej i statusu mniejszości narodowych, ale jako votum nieufności dla rządzącej ekipy. Rozczarowanie werdyktem wyborców zachwiało przekonaniem, że dominacji PDSh żadne ugrupowanie polityczne nie będzie w stanie zagrozić. Oznaczało to zarazem podjęcie działań prawnych, zmierzających do stworzenia

${ }^{5}$ F. Lubonja, Piramidy z błota, [w:] idem, Albania - wolność zagrożona. Wybór publicystyki z lat 1991-2002, przekł., oprac. i wybór D. Horodyska, Sejny 2005, s. 279.

${ }^{6}$ P. Sloterdijk, Gniew i czas. Esej polityczno-psychologiczny, przeł. A. Żychliński, Warszawa 2011, s. 215. 
modelu faktycznej monopartyjności. Kluczową rolę miała odegrać ustawa o ludobójstwie z września 1995 r. Wpisywała się ona w typowe dla państw postkomunistycznych działania zmierzajace do lustracji życia publicznego, ale wprowadzała rozwiązania najbardziej radykalne, a zarazem obliczone na osiagnięcie doraźnych korzyści politycznych w obliczu nadchodzacych wyborów parlamentarnych ${ }^{7}$. Realizacja ustawy umożliwiła eliminacje z list partii opozycyjnych ponad 100 osób, oskarżonych o działalność w komunistycznym aparacie władzy, a także o współpracę z komunistyczną służbą bezpieczeństwa (Sigurimi). O arbitralnym stosowaniu ustawy w praktyce świadczył choćby fakt, że jej konsekwencje dotknęły zaledwie trzech polityków rządzącej partii, podczas gdy kierownictwo największej partii opozycyjnej - Socjalistycznej Partii Albanii - zostało na mocy ustawy zdziesiątkowane. Wzmocnienie przewagi PDSh miały przynieść także zmiany legislacyjne. Nowa ordynacja wyborcza zapewniała absolutna większość partii, która odniesie zwycięstwo w wyborach. W wyborach majowych 1996 r. na Demokratyczną Partię Albanii głosowało 55\% wyborców, ale według nowej ordynacji zapewniło to jej 122 mandaty (na 140).

${ }^{7}$ Uchwalona 22 września 1995 r. Ustawa o ludobójstwie i zbrodniach przeciwko ludzkości popetnionych w Albanii w okresie rzadów komunistycznych $z$ motywów politycznych, ideologicznych $i$ religijnych wprowadzała dla byłych funkcjonariuszy Albańskiej Partii Pracy, urzędników wyższego szczebla i informatorów Sigurimi zakaz sprawowania urzędów publicznych do roku 2002. Na jej podstawie zdyskwalifikowano 142 kandydatów do parlamentu, „Fletorja Zyrtare e Republikës së Shqipërisë” Nr. 21, Shtator 1995, s. 923-924; B.J. Fisher, op. cit., s. 466. 
Socjaliści przy trzykrotnie mniejszym poparciu zdobyli zaledwie 10 mandatów ${ }^{8}$.

Jeszcze przed zakończeniem głosowania pierwsze sygnały o klęsce skłoniły opozycję do opuszczenia komisji wyborczych, a następnie do organizowania serii wieców, w proteście przeciwko nieprawidłowościom w czasie wyborów. Opinie zagranicznych obserwatorów były rozbieżne w ocenie albańskich wyborów: bardzo krytyczny raport przedstawiła Organizacja Bezpieczeństwa i Współpracy w Europie (OBWE), ale już raport Rady Europy prezentował bardziej umiarkowane stanowisko. Potwierdzał on, że doszło do nieprawidłowości, ale dotyczyło to kilku okręgów i nie miały one większego wpływu na ostateczny wynik ${ }^{9}$.

Ograniczenie wpływów PSSh w parlamencie do zaledwie 10 mandatów oznaczało koniec silnej formacji politycznej na lewicy i groziło rozłamem w partii. Szansę na przetrwanie szukali przywódcy partii w wysyłaniu kolejnych apeli do społeczności międzynarodowej o wywarcie presji na S. Berishę, aby zgodził się na kolejne, tym razem „praworządne" wybory. Główna partia opozycyjna przyjęła taktykę bojkotu obrad nowego parlamentu i głoszenia tezy o sfałszowanym głosowaniu, które należy powtórzyć. Wybory lokalne w październiku 1996 r. potwierdziły dominację Partii

${ }^{8}$ E. Biberaj, Shqipëria në tranzicion. Rruga e vështirë drejt Demokracisë, Tirana 2001, s. 450-451.

${ }^{9}$ The Albanian Parlamentary Elections of 1996, http://www.osce.org/ odihr/elections/albania/13567 (dostęp 12 II 2014); Resolution 1095 (1996) on the recent parliamentary elections in Albania, http://assembly.coe.int/Main. asp?link=/Documents/AdoptedText/ta96/ERES1095.htm (dostęp 12 II 2014). 
Demokratycznej, która odniosła zwycięstwo w 58 spośród 64 okręgów wyborczych ${ }^{10}$.

Polityczny spór dwóch największych partii zdecydowana większość społeczeństwa albańskiego przyjmowała z obojętnością. Podstawowe kryteria oceny rządzącej partii odnosiły się do aktualnej sytuacji ekonomicznej, a wzrost o $6 \%$ produkcji przemysłowej w $1996 \mathrm{r}$. skłaniał do postaw umiarkowanie optymistycznych i zniechęcał do radykalnych zmian ${ }^{11}$. Nie udało się, co prawda, pokonać dwóch największych bolączek albańskiej gospodarki - wysokiej skali bezrobocia (przekraczającej 20\%) i niewielkiej skali inwestycji obcego kapitału, ale malejąca inflacja i wyciszenie sporów albańsko-greckich umożliwiało zaspokojenie podstawowych potrzeb dzięki zarobkom członków rodzin pracujących „na czarno” w Grecji i we Włoszech. Dochody z pracy gastarbeiterów w skali roku szacowano na 0,8-1 mld dolarów. Wojna w Jugosławii i embargo paliwowe, narzucone na ten kraj, otworzyły możliwości działania Albańczyków w tzw. szarej strefie paliwowej. Równie intratne stawały się zyski z przemytu ludzi do Włoch i z handlu narkotykami ${ }^{12}$.

Ubogi rynek wewnętrzny, nieuregulowane kwestie własnościowe i niewydolny system bankowy nie pozwalały na inwestowanie nadwyżek pochodzacych od imigrantów, ale także utrudniały obrót tzw. brudnych pieniędzy, pochodzących z nielegalnego handlu i przemytu. Od 1995 r. jedyną szansę na korzystne inwestowanie stwarzały tzw. piramidy

${ }^{10} \mathrm{~W}$ wyborach lokalnych socjaliści uzyskali zaledwie 6,25\% głosów, co pozwoliło im na zwycięstwo w czterech okręgach wyborczych, E. Biberaj, op. cit., s. 473.

${ }^{11}$ T. Perlmutter, The Politics of Proximity: The Italian Response to the Albanian Crisis, „International Migration Review” 1998, vol. 32, no. 1, s. 206.

${ }^{12}$ T. Gallagher, The Balkans after the Cold War. From Tyranny to Tragedy, London-New York 2003, s. 168. 
finansowe. Mechanizm piramidy, którego twórca miał być włoski hochsztapler Charles Ponzi, opiera się na wypłacie wysokich zysków klientom, którzy zainwestowali jako pierwsi, dzięki wpłatom kolejnych osób wpłacających w późniejszym terminie. Warunkiem przetrwania piramidy jest stały wzrost liczby nowych klientów, którzy tworzą jej podstawę. W państwach postkomunistycznych najlepszym okresem dla tworzenia tego typu przedsięwzięć były pierwsze lata transformacji ekonomicznej. W firmie MMM, kierowanej przez Siergieja Mawrodiego, „utopiło” swoje oszczędności 5 mln Rosjan. Podobnym „sukcesem”, choć na mniejszą skalę, mógł „poszczycić się" Ion Stoica, założyciel rumuńskiej firmy Caritas ${ }^{13}$. Przedsięwzięcia tego typu pojawiły się w Albanii już w 1991 r., ale faza ich gwałtownego rozwoju przypadła na lata 1995-1996. Większość funduszy, opierających swoją działalność na systemie piramidy finansowej, w pierwszej fazie swojego istnienia pozyskiwała kapitał z kantorów wymiany walut lub z gier losowych ${ }^{14}$. Boom piramidowy eksplodował w 1996 r., kiedy blisko połowa, spośród liczącej 3,3 mln ludności Albanii, stała się klientami funduszy. Inwestowano nie tylko zgromadzone przez lata oszczędności, ale także kredyty uzyskane pod zastaw mieszkań ${ }^{15}$. Większość klientów stanowili mieszkańcy południowo-zachodniej części kraju, gdzie najszybciej

${ }^{13}$ K. Verdery, Faith, Hope and Caritas in the Land of the Pyramids: Romania, 1990 to 1994, „Comparative Studies in Society and History” 1995, vol. 37 , no. 4 , s. $626-627$.

${ }^{14}$ Wyjątek stanowiła VEFA, działająca od 1992 r. jako firma handlowa, i Populli (Lud), określana początkowo jako instytucja charytatywna.

${ }^{15}$ Christopher Jarvis szacuje liczbę klientów ośmiu największych funduszy w ostatniej fazie ich działalności na 1687 tys. osób, z czego 1188 tys. zgromadził działajacy od $1996 \mathrm{r}$. fundusz Xhaferri, Ch. Jarvis, The Rise and Fall of the Pyramid Schemes in Albania, „IMF Staff Papers” 2000, vol. 47, no. 1 , s. 10. 
rozwijała się tzw. szara strefa; z południa pochodziła także większość gastarbeiterów. Piramidy finansowe oferowały w swoim najlepszym okresie zyski na poziomie 10-100\% miesięcznie, w czasie kiedy oprocentowanie wkładów bankowych nie przekraczało 20\% rocznie $^{16}$. Możliwość podwojenia w krótkim czasie majątku (a takie przypadki w pierwszej fazie działania funduszy obserwowano) rozpalała wyobraźnię. Mit bogactwa bez wysiłku i pracy rodził przekonanie, że znalazł się sposób na wyleczenie społecznej frustracji, którą przyniosło pojawienie się kapitalizmu w kraju tak biednym, jak Albania. Christopher Jarvis, analizując albański boom piramidowy, zwracał uwagę na specyfikę społeczeństwa, pozbawionego w okresie komunizmu podstaw wiedzy ekonomicznej i możliwości oszacowania realnych zysków z zainwestowanych środków ${ }^{17}$. Do inwestowania w piramidy zachęcały reklamy zamieszczane $\mathrm{w}$ prasie, $\mathrm{w}$ tym także tytuły związane $\mathrm{z}$ opozycja. Na łamach opozycyjnego pisma „Koha Jone” w październiku 1996 r. ukazał się artykuł Bena Blushiego, który nie widział nic złego w rozwoju funduszy piramidowych i krytykował uległość rządu wobec dyrektyw Międzynarodowego Funduszu Walutowego, domagającego się ich likwidacji ${ }^{18}$.

Mimo ostrzeżeń płynących ze strony międzynarodowych instytucji finansowych, zablokowanie działalności funduszy nie wchodziło w grę przed wyborami lokalnymi w październiku 1996 r. ${ }^{19}$ Do 1996 r. prawo albańskie nie zabraniało lokowania pieniędzy z zamiarem uzyskania wysokich odsetek.

${ }^{16}$ Ibidem, s. 6.

${ }^{17}$ Ibidem, s. 26.

${ }^{18}$ E. Biberaj, op. cit., s. 482.

${ }^{19}$ W sierpniu i wrześniu 1996 r. przebywała w Tiranie misja Międzynarodowego Funduszu Walutowego, która wyraziła zaniepokojenie rozwojem funduszy piramidowych i ich negatywnym wpływem na albański system bankowy, ibidem, s. 13 . 
Dopiero zapis w ustawie bankowej, uchwalonej przez parlament w lutym 1996 r., stanowił formalna podstawę do likwidacji funduszy, jeśli nie uzyskają od banku stosownej koncesji. Zadania interpretacji tej ustawy podją się prokurator generalny, odrzucając zarzuty prezesa Banku Albanii stwierdzeniem, że zakaz przyjmowania depozytów od ludności nie dotyczy tego typu firm, jak fundusze pożyczkowe ${ }^{20}$. W listopadzie $1996 \mathrm{r}$. miały miejsce pierwsze bankructwa funduszy opartych na systemie piramidy, w tym firmy Arkond (działającej głównie we Wlorze) oraz Sudja, której wierzycielami byli przeważnie mieszkańcy Tirany. Upadłość firm nie okazała się wystarczającym sygnałem ostrzegawczym tym bardziej, że w pierwszych takich przypadkach udało się odzyskać większość środków zainwestowanych, a samo bankructwo tłumaczono relatywnie niskim oprocentowaniem oferowanym przez bankrutów (na poziomie 10-30\% miesięcznie). Konkurencyjne firmy, jak choćby działajacca we Wlorze Gjallica czy Xhaferri w Lusznji, proponowały inwestorom oprocentowanie kilkukrotnie wyższe, a efektowne decyzje marketingowe nie zapowiadały ich rychłego krachu ${ }^{21}$.

Anemiczne dotąd działania władz wobec problemu piramid finansowych uległy wyraźnemu przyspieszeniu pod koniec grudnia 1996 r., wraz z utworzeniem komisji parlamentarnej, zobowiązanej do kontroli ich działalności. Powiązania czołowych polityków z szefami największych

${ }^{20}$ Ch. Jarvis, op. cit., s. 7-8.

${ }^{21}$ Przykładem takich działań było pozyskanie przez właścicieli firmy Xhaferri dwóch piłkarzy brazylijskich do klubu piłkarskiego KS Lusznja, a także Argentyńczyka Mario Kempesa, który za 300 tys. dolarów rocznie zdecydował się objąć posadę jego selekcjonera. Kempes pracował w Lusznji przez dwa miesiące, A. Krasniqi, Rënia e demokracisë: Shqipëria në muajt janar-qershor 1997: publicistikë, politikë, Tirana 1997, s. 93-94; F. Chaine, Matador: Mario A. Kempes: biografía, Valencia 2003, s. 129-130. 
firm piramidowych nie pozostawiały złudzeń, że ci ostatni będą na bieżąco informowani o harmonogramie działań legislacyjnych $\mathrm{w}$ sprawie funduszy ${ }^{22} .5$ stycznia $1997 \mathrm{r}$. doszło do zawarcia pierwszego porozumienia pomiędzy funduszami VEFA i Kamberi o ujednoliceniu zasad działania i obniżeniu oprocentowania dla nowych inwestorów. Nie przystapili do niego przedstawiciele funduszy Gjallica i Xhaferri. Te dwie największe firmy podwyższyły oprocentowanie wkładów do poziomu $100 \%$ miesięcznie, co pozwoliło im w początkach stycznia 1997 r. odciagnąc klientów od bardziej „ostrożnych” funduszy.

Informacja o wywiezieniu $\mathrm{w}$ nocy z 9 na 10 stycznia 1997 r. z Wlory aktywów największych funduszy pojawiła się jako pierwsza w albańskojęzycznym serwisie „Głosu Ameryki”, a w poniedziałek 13 stycznia informację tę powtórzyły dzienniki związane z socjalistyczną opozycja. Według ostrożnych szacunków, na pokładzie motorówki, płynącej noca do Włoch, znalazło się 300-700 mln dolarów. Zablokowanie aktywów działających wciąż funduszy i aresztowanie 50 osób związanych z funduszami, którzy nie zdążyli opuścić kraju, okazało się spóźnioną reakcją państwa na narastający kryzys i nie wpłynęło na uspokojenie nastrojów społecznych ${ }^{23}$. Ogłaszane kolejno bankructwa funduszy uświadamiały ich klientom, że nie tylko nie mogą liczyć na bajeczne zyski, ale trudno im będzie odzyskać zainwestowane pieniądze. Rosnacy szybko wskaźnik inflacji i tak oznaczał znaczne straty, nawet przy zwrocie zainwestowanych środków. Gniew oszukanych kierował się nie przeciwko właścicielom piramid, ale i tym, którzy czerpali z nich zyski i mieli przyspieszyć ich bankructwo,

${ }^{22}$ Jeszcze w listopadzie 1996 r. urzędujacy premier Albanii i przewodniczący parlamentu uczestniczyli w obchodach 5. rocznicy działalności firmy VEFA i otrzymali od jej prezesa pamiątkowe medale, Ch. Jarvis, op. cit., s. 8.

${ }^{23}$ E. Biberaj, op. cit., s. 483. 
czyli w stronę polityków rządzącej partii. Oburzenie bankrutów sprzyjało odzyskiwaniu autorytetu i wpływów politycznych przez socjalistyczną opozycję, która mogła wystapić jako polityczne zaplecze „ruchu pokrzywdzonych”. Po ogłoszeniu w początkach lutego bankructwa funduszu Gjallica doszło do regularnej bitwy demonstrantów z policją w Lusznji, zakończonej wypędzeniem z miasta interweniujących oddziałów. Eskalacji kryzysu sprzyjały komentarze w prasie opozycyjnej, ubolewające nad brakiem „ducha sprzeciwu” wśród Albańczyków i identyfikujące się z postawami demonstrantów atakujących policję i instytucje państwowe ${ }^{24}$.

Momentem przełomowym, który zdecydował o przejściu od fazy spontanicznych demonstracji do „buntu” czy też „powstania ludowego", stały się zamieszki, do których doszło we Wlorze. Straty jej mieszkańców, związane z krachem piramid, były większe niż w innych miastach. Wśród pokrzywdzonych byli także przedstawiciele wyjątkowo licznego tu kryminalnego półświatka. Napięcie we Wlorze narastało od 20 lutego, kiedy to 54 studentów miejscowego uniwersytetu rozpoczęło strajk głodowy, domagając się zwiększenia nakładów na uczelnię i rozbudowy jej infrastruktury. 28 lutego w godzinach wieczornych kilkudziesięcioosobowa grupa zamaskowanych mężczyzn zaatakowała budynek komendy policji i siedzibę policji politycznej - Narodowej Służby Informacyjnej (Sherbimi Informativ Kombëtar, ShIK), a następnie lokalny komitet Demokratycznej Partii Albanii ${ }^{25}$. W ataku zginęło dziewięć osób, a napastnicy przejęli znaczne zasoby broni i amunicji. Dzień później działające dotąd struktury władzy w mieście praktycznie przestały funkcjonować, a władzę nad

${ }^{24}$ Ibidem, s. 485.

${ }^{25}$ M. Valevski, Albanija 1990-1997. Sowremeni demokratski preobrazbi, reformi i kontrowerzi, Skopje 1998, s. 412. 
ulicami przejęli uzbrojeni cywile. W kolejnym dniu w ręce buntowników wpadły Saranda, Delvina i Himara, a w Lusznji demonstrujący tłum spalił pojazdy należące do policji.

2 marca 1997 r. parlament ogłosił w całym kraju stan wyjątkowy, a rząd Aleksandra Meksiego podał się do dymisji. Ustawa o stanie wyjątkowym wprowadzała godzinę policyjną i cenzurę prewencyjna, zakazywała zgromadzeń i demonstracji. Po dymisji rządu inicjatywę polityczną próbowała przejąć opozycja socjalistyczna. Powołane przez nią Forum na rzecz Demokracji, złożone z przedstawicieli 11 partii i ugrupowań politycznych, zaproponowało prezydentowi utworzenie rządu porozumienia narodowego z reprezentantów największych partii, ale propozycja ta została odrzucona. W emocjonalnym przemówieniu do narodu, transmitowanym przez radio i telewizję, prezydent S. Berisha określił sytuację we Wlorze mianem „terrorystycznego buntu”. Wina za jego zorganizowanie obciążył byłych funkcjonariuszy komunistycznej służby bezpieczeństwa, działających w porozumieniu z obcymi agentami. Zagroził także użyciem radykalnych środków przeciwko „czerwonym terrorystom”, którzy dążą do unicestwienia przemian demokratycznych, jak też zniszczenia państwa albańskiego ${ }^{26}$. Postawę umiarkowania i otwarcia na dialog z protestującymi doradzała Berishy ambasador USA w Tiranie, Marisa Lino, a także dyplomaci włoscy i greccy. Wbrew ich stanowisku, prezydent zdecydował się na kolejny krok, który nieuchronnie prowadził do zaognienia sytuacji. Zebrany na nadzwyczajnym posiedzeniu parlament Albanii 3 marca 1997 r. wybrał Berishę na urząd prezydenta (mimo iż jego kadencja upływała dopiero 9 kwietnia). Od tej pory hasło dymisji prezydenta stało się głównym postulatem, zgłaszanym przez zbuntowane południe kraju.

${ }^{26}$ Ibidem, s. 413. 
Od wydarzeń we Wlorze Berisha nie widział możliwości ani sensu rozmowy z demonstrantami, a zaistniałe problemy zamierzał rozwiązać siła. Plan pacyfikacji Południa, który miały przeprowadzić regularne jednostki wojskowe, okazał się pasmem niepowodzeń. Po zdymisjonowaniu szefa sztabu armii albańskiej, gen. Shema Kosovy, jego miejsce zają dotychczasowy doradca prezydenta, gen. Adem Çopani, który dla większości oficerów był tylko funkcjonariuszem ShIK i nie posiadał autorytetu ani charyzmy poprzednika ${ }^{27}$. Oficerowie armii albańskiej, wyszkoleni w duchu ideałów „demokratycznej armii w demokratycznym społeczeństwie”, odmawiali strzelania do buntującego się narodu, nawet jeśli stwarzał on zagrożenie porządku publicznego ${ }^{28}$. Po upadku Gjirokastry, w dniu 9 marca, praktycznie cała południowo-zachodnia Albania znalazła się w rękach rebeliantów. Oznaczało to także utratę magazynów wojskowych, fabryki broni, a nawet czterech lotnisk wojskowych z pełnym wyposażeniem. Symbolami postępujacego procesu anarchizacji stały się spalone siedziby banków i zrujnowane budynki należące do PDSh.

${ }^{27}$ Opcja zerowa, przyjęta w latach 1992-1997, zakładała, że podstawowym elementem restrukturyzacji armii powinna być radykalna wymiana kadr tak, aby usunać „oficerów enwerystów” z okresu reżimu komunistycznego i zastapić ich młodszą kadra, związana politycznie z Partią Demokratyczna, zob. H. Katana, Ringritja e Ushtrisë Shqiptare, '97-2000, Tirana 2004, s. $14-15$.

${ }^{28}$ Genezę konfliktu armii i służb specjalnych próbuje wyjaśnić były szef ShIK w Pogradecu, Andrea Dimushi, który w 2015 r. udzielił wywiadu dla czasopisma „Dita”. Z jego relacji wyłania się obraz postępującej degeneracji służb odpowiedzialnych za bezpieczeństwo w kraju, które w okresie rządów PDSh zostały opanowane przez rodzinne klany z Dibry i Tropoji, eliminując ze stanowisk kierowniczych osoby spoza „układów klanowych”, zob. A. Dimushi, Unë, Gazidede dhe të vërtetat për SHIK-un deri më 1997, „Dita”, 20 V 2015, http://www.gazetadita.al/20-maj-2015/ (dostęp 4 VI 2015). 
Raporty o zbliżającej się do stolicy fali przemocy ostatecznie przekonały kierownictwo Partii Demokratycznej do podjęcia dialogu z opozycja. Przy pomocy ambasadora Włoch w Tiranie, Paolo Forestiego, i przedstawicieli OBWE doszło do rozmów Berishy z delegacją Forum na rzecz Demokracji. Ich efektem było zawarcie 9 marca porozumienia głównych sił politycznych. Zakładało ono utworzenie wielopartyjnego Rzadu Pojednania Narodowego, przeprowadzenie przedterminowych wyborów, zniesienie cenzury i powszechną amnestię (nie dotycząca osób, które popełniły przestępstwa kryminalne). Na czele rządu miał stanać Bashkim Fino, prezydent Gjirokastry w latach 1992-1993, związany z PSSh. W tym czasie własne organy władzy powołali także „buntownicy z Południa”. Nosiły one nazwę komitetów ocalenia narodowego i aspirowały do kontroli nad poszczególnymi miastami południa, choć ich realna władza nad tysiącami uzbrojonych ludzi wydawała się iluzoryczna. 12 marca przedstawiciele 14 komitetów powołali jednolity Komitet Wyzwolenia Narodowego, z siedzibą w Gjirokastrze, i wysunęli żądanie udziału delegatów w rozmowach na temat nowego rządu ${ }^{29}$. Negocjacji z delegatami Komitetu podjął się desygnowany na premiera, B. Fino, a toczyły się one na pokładzie włoskiej fregaty „Aliseo”, która zacumowała w pobliżu Wlory. Głównym postulatem, wysuwanym w toku rozmów, było żądanie politycznej „neutralizacji” S. Berishy, a zwłaszcza pozbawienia go kontroli nad służbami specjalnymi i nad mediami ${ }^{30}$.

Kulminacja albańskiej „krwawej wiosny” miała miejsce w dniach 12-14 marca, kiedy postępująca destrukcja państwa objęła również stolicę - pod kontrolą władz centralnych

${ }^{29}$ R. Bideleux, I. Jeffries, The Balkans: A Post-Communist History, London 2007, s. 56.

${ }^{30}$ M. Valevski, op. cit., s. 421. 
pozostało nie więcej niż kilka kilometrów kwadratowych kraju. Miasto opuściła większość obcokrajowców; opustoszały także wszystkie więzienia w kraju. Rabunkom stołecznych magazynów i sklepów towarzyszyły „rajdy” po ulicach miasta zdobytych przez demonstrantów samochodów policyjnych. Stolicę uratowało kilkuset policjantów i ochotników, zwerbowanych przez oficerów z II Komisariatu Policji w Tiranie, którzy strzegli budynków rządowych w najtrudniejszych chwilach. Do 15 marca słychać było strzały na przedmieściach Tirany, ale - wbrew obawom mieszkańców - główne siły rebeliantów do miasta nie dotarły ${ }^{31}$.

Już w następnym dniu po opanowaniu sytuacji w Tiranie, 14 marca parlament jednomyślnie poparł kandydaturę B. Fino jako nowego szefa rządu. Odtwarzanie funkcji państwa, którym zają się nowy gabinet, polegało przede wszystkim na zapewnieniu ciagłości wypłat uposażeń w sferze budżetowej i na odzyskiwaniu broni od ludności. Przed wyznaczonymi na czerwiec 1997 r. przedterminowymi wyborami parlamentarnymi złagodzono ustawę o ludobójstwie, ograniczając do minimum liczbę suspendowanych (członkowie Biura Politycznego partii komunistycznej i osoby skazane prawomocnie za zbrodnie przeciwko ludzkości). Odtwarzaniem struktur władzy cywilnej na zbuntowanym Południu zają się specjalny wysłannik premiera - Ibrahim Imami, w porozumieniu z gen. Agimem Gozhita, uznawanym przez buntowników za „komendanta Południa"32. Ochronę wyborów zapewniały, obok albańskiej policji, także Międzynarodowe Siły Pokojowe, działające

${ }^{31}$ J. Pettifer, M. Vickers, The Albanian Question. Reshaping the Balkans, London 2007, s. 44.

${ }^{32}$ Generał Agim Gozhita był w latach 1994-1996 dowódcą dywizji piechoty stacjonującej w Gjirokastrze, w 1996 r. przeniesiony w stan spoczynku, K. Halili, Fjalor biografik ushtarak, Tirana 2006, s. 59-60. 
zgodnie z rezolucją nr 1101 Rady Bezpieczeństwa Organizacji Narodów Zjednoczonych z 28 marca 1997 r. ${ }^{33}$

Kryzys państwa w 1997 r. spowodował rozpad armii, liczącej do tego czasu około 25 tys. oficerów i żołnierzy. Nieliczne jednostki podjęły walkę z rebeliantami, ale wobec wysokiej skali dezercji działania te tylko w niewielkim stopniu spowolniły marsz rebeliantów na północ. Większość oficerów w służbie czynnej rozeszła się do domów, nie podejmując walki w obronie skompromitowanego reżimu, zaś wielu żołnierzy, odbywających służbę wojskowa, przyłączyło się do demonstrantów ${ }^{34}$. Formalnie odrodzenie albańskich sił zbrojnych nastapiło w sierpniu. Ministerstwo Obrony apelowało do oficerów rezerwy o zgłaszanie się w celu uzupełnienia braków kadrowych. Po zmianie ekipy rządzącej z armii usuwano oficerów „niedoświadczonych" (w większości związanych politycznie z Demokratyczną Partią Albanii), a ich miejsce zajmowali ci, którzy przed 1997 r. w ramach redukcji korpusu oficerskiego zostali skierowani do rezerwy ${ }^{35}$. Około 30 mld lirów na odbudowę albańskich sił zbrojnych przeznaczyły Włochy, skąd przybyło 15 oficerów pomagających w procesie restrukturyzacji armii. Pomoc ta okazała się wyjątkowo cenna w zakresie zabezpieczania magazynów wojskowych, zwłaszcza tych z amunicją i materiałami wybuchowymi, oraz przechowywania środków

${ }^{33}$ Operacja „Alba”, którą realizował kontyngent, obejmowała także nadzorowanie rozdziału pomocy humanitarnej. Mandat kontyngentu trwał 45 dni, a w jej składzie znalazło się 7214 żołnierzy z 10 krajów, z czego prawie połowę stanowili Włosi, Resolution 1101 (1997) Adopted by the Security Council at its 3758th meeting, on 28 March 1997, http://www.refworld.org/ cgi-bin/texis/vtx/rwmain?docid=3b00f16e64 (dostęp 12 II 2014); T. Perlmutter, op. cit., s. 207-208.

${ }^{34}$ J. Kim, Albania: Country Background Report, [w:] The Balkans, ed. C. Watkins, New York 2003, s. 79.

${ }^{35}$ B. Vankovska, H. Viberg, op. cit., s. 59. 
niebezpiecznych. Akcja odzyskiwanie broni, która znalazła się w rękach ludności cywilnej, powiodła się tylko w niewielkim stopniu. Odzyskano głównie broń ciężką i chińskie rakiety przeciwlotnicze, stanowiące realne zagrożenie dla samolotów cywilnych. Znacznie trudniej było odzyskać broń ręczna, która trafiła do domowych „arsenałów” albo została sprzedana do Kosowa lub do Włoch ${ }^{36}$.

Zwycięstwo Partii Socjalistycznej w wyborach czerwcowych pozwoliło jej na samodzielne przejęcie władzy. Koalicja socjalistów z partią mniejszości greckiej zdobyła $61,6 \%$ głosów (118 mandatów), zaśs druga koalicja, skupiona wokół Partii Demokratycznej - 30,86\% (30 mandatów) ${ }^{37}$. Po wyborach powstał rząd koalicyjny, kierowany przez Fatosa Nano, w skład którego weszła PSSh, a także Partia Socjaldemokratyczna, Alians Demokratyczny i mniejszościowy Związek Obrony Praw Człowieka. Dramatyczne wydarzenia roku 1997 przyniosły istotne przewartościowanie albańskiej sceny politycznej. Podział na „Albanię socjalistów” i „Albanię demokratów” stał się znacznie mniej czytelny. W Partii Socjalistycznej doszła do głosu młodsza generacja polityków, którzy w początkach lat 90 . XX w. kończyli studia i zaczynali karierę $\mathrm{w}$ całkiem innej rzeczywistości niż ich starsi koledzy. W lipcu 1997 r. podał się do dymisji prezydent S. Berisha, podkreślając, że jego moralnym i patriotycznym obowiązkiem było pozostanie na stanowisku do końca pięcioletniej kadencji, ale nie widzi możliwości współpracy z rządzącą Partią Socjalistyczna. Na jego miejsce parlament wybrał dotychczasowego sekretarza generalnego PSSh - Rexhepa Mejdaniego.

${ }^{36} \mathrm{~W}$ trakcie wydarzeń marcowych $\mathrm{z}$ arsenałów albańskich zniknęło około 800 tys. sztuk broni oraz ponad 10 mld nabojów, M. Renner, Small Arms, Big Impact; The Next Challenge of Disarmament, „Worldwatch Paper" 1997, [no.] 137, s. 35.

${ }^{37}$ E. Biberaj, op. cit., s. 510-511. 
Wskaźniki makroekonomiczne, określające stan gospodarki albańskiej w 1997 r., można porównać z tymi, które charakteryzuja gospodarkę państw prowadzących działania wojenne lub doświadczających skutków klęski żywiołowej. W 1997 r. zanotowano spadek PKB o 7\% w porównaniu z 1996 r. (15,5\% per capita), spadek płac realnych o $22 \%$, aż o $42 \%$ spadła wartość albańskiego eksportu ${ }^{38}$. Firmy prowadzące fundusze piramidowe zostały objęte nadzorem przez centralną komisję i mianowanego przez rząd głównego administratora funduszy, Farudina Arapi. Wyprzedaż majątku funduszy rozpoczęła się w lipcu 1998 r. Jego wycena zajęły się dwie firmy audytorskie: Deloitte \& Touche oraz Coopers \& Lybrand, a sfinansował ją Bank Światowy. Wartość majątku firm oszacowano na 50 mln dolarów, przy zobowiązaniach sięgających 348 mln dolarów. Tylko w przypadku najmniejszych funduszy udało się zwrócić pieniądze ich klientom. Skutki ekonomicznej depresji, wywołanej krachem piramid w 1997 r., tylko częściowo złagodziła wojna w Kosowie 1999 r., kiedy to napływ ogromnej liczby uchodźców, a także jednostek NATO, najpierw zagroził katastrofą humanitarna, aby następnie stać się kołem zamachowym albańskiej gospodarki. Rozwój infrastruktury niezbędnej dla uchodźców przyczynił się do wzrostu zatrudnienia, szczególnie w zagrożonym wysokim bezrobociem regionie północno-wschodnim.

W wymiarze społecznym najtragiczniejszym aspektem „krwawej wiosny” była śmierć ponad 200 osób, które zginęły w czasie walk, w wyniku samosądów, a także nieumiejętnego posługiwania się bronią. Widmo nędzy, pogłębionej przez nagły wzrost inflacji, zagroziło tym wszystkim, którzy nie mogli liczyć na zastrzyk gotówki od krewnych pracujących za granica. Upadek piramid finansowych rozpoczął drugą (po 1991 r.)

${ }^{38}$ H. Mara, Tiparet e tranzicionit dhe strategiia e zhvillimit ekonomik të Shqipërisë, Tirana 2002, s. 28. 
„wielką ucieczkę" z Albanii. Tylko w pierwszym tygodniu marca do włoskiej Puglii dotarło 10619 nielegalnych uchodźców ${ }^{39}$. Największą skalę migracji notowano w dwóch miastach wybrzeża: Sarandzie i Wlorze, które w tym czasie opuściła połowa mieszkańców. Doświadczenie drugiej fali migracji stawało się udziałem całych rodzin, ale także młodych, wykształconych ludzi, którzy nie wiązali swojej przyszłości z rodzinnym krajem. Wyraźny wzrost udziału kobiet wśród emigrantów po $1997 \mathrm{r}$. wynika z tendencji do łączenia rodzin, a więc zmiany migracji czasowej na trwałe osiedlenie się w kraju przeznaczenia ${ }^{40}$. W gronie emigrantów „drugiej fali” znalazło się także liczne grono artystów i twórców, dla których często wyjazd oznaczał koniec kariery artystycznej. Głównym celem migracji 1997 r. stały się Włochy. Wśród zróżnicowanego pod względem narodowym i etnicznym środowiska emigrantów tam żyjących Albańczycy stali się grupą dominująca ${ }^{41}$.

Albania doświadczała także intensywnych migracji wewnętrznych. Spis powszechny z $2001 \mathrm{r}$. wykazał, że kraj ten pozostaje w gronie państw o najniższym wskaźniku urbanizacji w Europie. Wpływ na to miały głównie północne i wschodnie obszary kraju, które stopniowo wyludniają się i „starzeja”. Z drugiej strony można zauważyć, typową dla Grecji, tendencję do koncentracji ludności w dwóch-trzech największych

${ }^{39}$ T. Perlmutter, op. cit., s. 203.

${ }^{40}$ C. Carletto, B. Davis, M. Stampini, A. Zezza, A Country on the Move: International Migration in Post-Communist Albania, „International Migration Review" 2006, vol. 40, no. 4, s. 773.

${ }^{41}$ Szacunkowe dane z 2011 r. wskazuja, że około 14\% Albańczyków urodzonych w Albanii mieszka na stałe we Włoszech, N. Mai, C. Paladini, Flexible Circularities: Integration, Return and Socio-Economic Instability within Albanian Migration to Italy, [w:] Circular Migration between Europe and its Neighbourhood. Choice or Necessity?, [ed. by] A. Triandafyllidou, Oxford 2013, s. 45. 
miastach. Obraz wymierającej albańskiej prowincji kontrastuje z przeludnioną Tirana czy Durrësem, do których przyjeżdża się coraz częściej na pobyt czasowy związany z poszukiwaniem pracy czy odwiedzinami u rodziny.

Doświadczenia 1997 r., kiedy niszczono nie tylko siedziby banków, ale także majątek firm prywatnych, zniechęcały potencjalnych inwestorów do tworzenia miejsc pracy w małych miejscowościach. We wsi Gurra, opisywanej przez Colina Lawsona i Douglasa Saltmarshe’a, po 1997 r. przestał istnieć zakład obuwniczy - jedyna większa firma zatrudniająca miejscową ludność. Mieszkańcy tej wsi ostatecznie stracili zaufanie do banków, pożyczając w razie potrzeby gotówkę od rodziny lub sąsiadów ${ }^{42}$.

Wydaje się, że większość Albańczyków do dzisiaj nie potrafi jednoznacznie odpowiedzieć na pytanie, co było główną przyczyną kryzysu 1997 r. i dlaczego, w obliczu zagrożenia, państwo albańskie okazało się tak kruche i bezradne. Zmiana ekipy rzadzącej po 1997 r. skłaniała do tworzenia teorii spiskowych, tłumaczących istotę kryzysu. Najbardziej rozbudowaną przedstawił 26 marca 1997 r. na forum parlamentu Bashkim Gazidede (kierujący w latach 1992-1996 policją polityczną ShIK). W jego przekonaniu, zbrojny bunt w południowej Albanii stanowił część greckiego planu o kryptonimie „Lotos”, którego celem było oddzielenie od Albanii tzw. Północnego Epiru i połączenie go z państwem greckim ${ }^{43}$. Czasopisma związane z partia S. Berishy dość jednoznacznie wskazywały na inspirowany z Aten spisek,

${ }^{42}$ C. Lawson, D. Saltmarshe, Security and Economic Transition: Evidence from North Albania, „Europe-Asia Studies” 2000, vol. 52, no. 1, s. $141,144$.

${ }^{43}$ M. Valevski, op. cit., s. 428. W wywiadzie udzielonym w 2006 r. B. Gazidede szacował, że ponad $70 \%$ osób kierujących albańskimi funduszami piramidowymi, wywodziła się ze struktur kierowniczych Sigurimi lub była w przeszłości zatrudniona w komunistycznym Ministerstwie 
w którym jedną z głównych ról miał odegrać nowy premier - F. Nano. Uzasadnienia dla tej tezy szukano w jego progreckich sympatiach, w składzie jego rządu, zdominowanego przez przedstawicieli południowej części kraju, a wreszcie w postawie greckich żołnierzy (uczestniczacych w operacji „Alba”), którzy mieli uzależniać rozdział pomocy humanitarnej od decyzji wyborczych Albańczyków ${ }^{44}$. Winnymi zapaści państwa uznawano także agentów greckich służb specjalnych lub agentów CIA, działających $\mathrm{w}$ interesie grecko-albańskiej socjalistycznej międzynarodówki. W rozważaniach o spisku obcych powracały dawne kompleksy albańskie wobec silniejszego sąsiada z południa, który miał wykorzystać niepokoje w Albanii do ponownego włączenia jej do strefy greckich interesów tak, by możliwe było korzystanie z taniej, albańskiej siły roboczej ${ }^{45}$. Dyskusja nad geneza i konsekwencjami „krwawej wiosny” uległa wyraźnemu ożywieniu w 2013 r., kiedy to zwycięstwo Socjalistycznej Partii Albanii w wyborach parlamentarnych skłaniało do dyskredytacji opozycyjnych sił politycznych, obciążanych odpowiedzialnością za kryzys państwa $\mathrm{w} 1997 \mathrm{r}{ }^{46}$

Spraw Wewnętrznych, B. Gazidede, Ja agjentët që organizuan '97, „Shekulli”, 27 X 2006.

${ }^{44}$ F. Schmidt, Conspiracy Theories in Albanian Politics and Media, [w:] Albanian Identities. Myth and History, eds. S. Schwandner-Sievers, B.J. Fischer, London 2002, s. 229.

${ }^{45}$ Ibidem, s. 230.

${ }^{46} \mathrm{~W} 2013$ r. w prasie albańskiej ukazała się seria wywiadów byłego pułkownika armii albańskiej, Hekurana Rrapaja, który oskarżył przywódców Demokratycznej Partii Albanii o przygotowanie rozkazu powszechnej mobilizacji albańskich sił zbrojnych w marcu 1997 r., opracowanie planu siłowego rozwiązania konfliktu, a także o zamiar użycia broni gazowej przeciwko demonstrantom, H. Rrapaj, Një dëshmi shokuese mbi një bisedë Shamata-Berisha nё '97, [rozm.] K. Borici, E. Habilaj, „Dita”, 24 IX 2013, http:// www.gazetadita.al/nje-deshmi-shokuese-mbi-nje-bisede-shamata-berishane-97/ (dostęp 4 VI 2015). 
Albańską lekcję 1997 r. Peter Sloterdijk określa jako typowy przykład błędnego rozumienia istoty kapitalizmu przez ludzi wychowanych w komunistycznej dyktaturze deficytu ${ }^{47}$. Złudzenia społeczne o powszechnym bogactwie i głównej wygranej dla wszystkich zdaja się być zbliżone do doświadczeń innych społeczeństw postkomunistycznych. Obserwacja zamieszek sofijskich, wywołanych przez zapaść ekonomiczna 1997 r., czy protestów społecznych 1999 r., do których doszło w Rumunii, wykazuje szereg analogii z doświadczeniami albańskiej wiosny 1997 r., choć w pozostałych przypadkach skala buntu nie doprowadziła do takiego stopnia anarchizacji państwa. Mirela Bogdani i John Loughlin wydarzenia „albańskiej wiosny” wpisuja w ciąg zdarzeń określanych jako druga fala rewolucji, ogarniających kraje postkomunistyczne u schyłku XX w., a prowadzących do obalenia skorumpowanych reżimów, wyniesionych do władzy na fali demokratycznych przemian ${ }^{48}$.

Badacze C. Lawson i D. Saltmarshe, prowadzacy w latach 1996-1997 badania nad społecznością dwóch wsi Malaj i Gurra (okręg Dibra), zwracali uwagę na powszechną obojętność, czy wręcz akceptację, dla działań bezprawnych i przestępczych, szczególnie dotyczących różnych form kradzieży i przemytu. Wiara w państwo jako instytucję sroga, ale opiekuńcza, podtrzymywana przez reżim E. Hoxhy, została poważnie nadwerężona wraz z pierwszą lekcją anarchii w latach 1990-1991, a upadła ostatecznie w efekcie „nadzorowanej przez państwo” kradzieży, dokonanej na szkodę społeczeństwa. Powszechna i spontaniczna kradzież mienia państwowego, do której doszło w 1997 r., stanowiła formę „odebrania państwu” utraconej własności. Była to też kolejna, akceptowana społecznie, kradzież

${ }^{47}$ P. Sloterdijk, op. cit., s. 219-220.

${ }^{48}$ M. Bogdani, J. Loughlin, Albania and the European Union. The Tumultuous Journey towards Integration and Accession, London 2007, s. 37. 
czasów transformacji - podobnie jak masowe kradzieże samochodów w Europie Zachodniej (przywożonych potem do Albanii), a także powszechny szmugiel paliwa i broni do Jugosławii, co stanowiło jedno z głównych źródeł utrzymania ubogich wsi w północnej części kraju. Dla wielu mieszkańców północnej Albanii wydarzenia $1997 \mathrm{r}$. wpisywały się w poczucie zagrożenia i niestabilności, którego doświadczali po upadku socjalizmu ${ }^{49}$. Nagły wzrost pospolitej przestępczości, z czym kojarzyli pierwsze lata demokracji, i bezradność policji wobec tego problemu drastycznie obniżyły poziom zaufania obywateli do własnego państwa i jego instytucji.

${ }^{49}$ C. Lawson, D. Saltmarshe, op. cit., s. 142. 